\title{
Irritability of the Pollen-presentation Mechanism in the Compositae.
}

\author{
BY \\ JAMES SMALL, M.Sc. (Lond.), Ph.C., \\ Assistant Lecturer in Botany, Bedford College, London University.
}

$\mathrm{N}$ view of the frequency with which this phenomenon has been found 1 during the past year in the Compositae and its appearance in several common British species, it has been thought advisable to publish this preliminary list of irritable species and varieties. The data form part of a thesis in course of preparation, therefore they will not be discussed fully. The present contribution aims only at recording those species in which irritability has been observed for the first time.

Few previous authors have recorded the exact type of irritability, and none has recorded the degree of irritability observed (1-8 and 11), but in the present list those hitherto neglected features of the phenomenon are recorded thus :

\section{Types of Irritability.}

A : pollen presented on touching; no lateral movement of the anther tube. B : ; lateral movement, indefinite in direction. C $\mathrm{C}^{1}$

$"$

"

”

$\mathrm{C}^{\mathrm{e}}:$,
; lateral movement towards the touch.

; lateral movement towards the centre of the capitulum.

with more or less explosive rapidity.

The degree of irritability is noted as slight when it requires careful observation, and notes are added on special cases.

The phenomenon has been well known in the Cynareae since the seventeenth century at least, but very few records are to be found in the literature of the subject of irritable species, even in the Cynareae. Juel (4) records thirty-five species in various tribes; Kolreuter (6) records twenty-three species of which thirteen are Centaureae, and other authors have recorded only a few more.

The method used in the present investigation was to touch the anther tube gently with a needle and observe the result with a watchmaker's 
eyeglass. The following precautions must be noted for successful observations :

(I) Irritability is shown only under good conditions of heat, light, and dryness. The movement is most active before 3 p.m. On cold or wet days species which show marked irritability under the proper conditions show very little or no movement.

(2) Irritability is frequently shown only after the anther tube has opened and before the style is exserted, but there are many exceptions to this rule, especially in the Cichorieae.

(3) Although several species continue to show irritability after the flowers have been removed from the plant, in most cases movement ceases after this treatment.

(4) The anther tube should be touched gently.

(5) The observation of the ' $A$ ' type of movement requires careful and sometimes prolonged examination of numerous florets before it can be recorded without doubt or considered absent altogether.

(6) Species which show ' $C$ ' under the best conditions may show ' $B$ ' or ' $A$ ' under less favourable conditions.

(7) Species here recorded as ' $A$ ' or ' $B$ ' may be found to show ' $C$ ' on examination in more favourable circumstances.

The list gives the name of species, place where observed for the first time, and type of irritability, with remarks on the degree of irritability. Many of the observations have been confirmed by colleagues, by students, or by the writer on different occasions. Altogether 233 species and varieties have been examined, and this investigation has yielded I 49 records of irritability, mostly new. To facilitate reference an ' $x$ ' has been placed opposite all British, introduced, or commonly cultivated species. In column 2 of the list K.R.B.G. = Royal Botanic Gardens, Kew ; E.R.B.G. = Royal Botanic Garden, Edinburgh; C.U.B.G. = Cambridge University Botanic Garden; C.P.G. = Chelsea Physic Garden; A.C.G. = Armstrong College Garden; $F_{0}=$ in the field. The numbers in brackets in the fourth column refer to the notes at the end of the list.

\section{Genus and Species.}

Achillea alpina, L.

Achillea Clavennae, L.

Achillea crustata, Schur.

Achillea grandiflora, Bieb.

Achillea holosericea, Sibth. and Sm.

Achillea magna, $\mathrm{L}$.

$\times$ Achillea millefolium, $\mathrm{L}$.

$\times$ Achillea Ptarmica, L.

Amellus annuus, Willd.

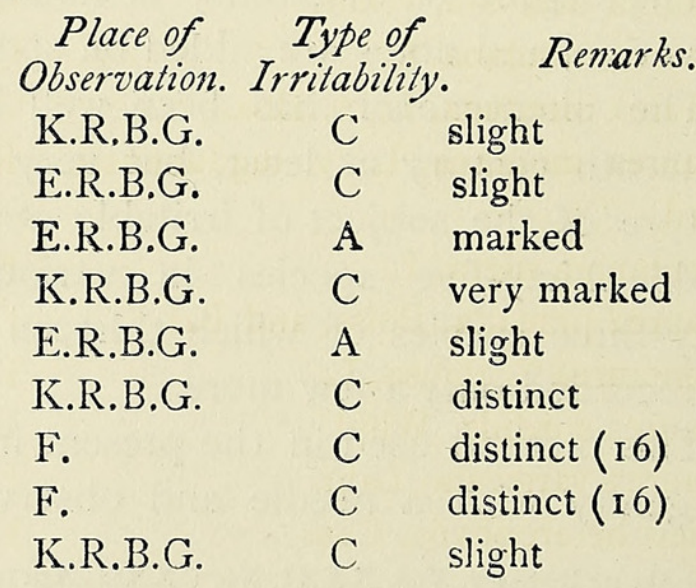




\section{Genus and Species.}

Ammobium alatum, R. Br.

Anacyclus officinarum, Heyne

Anaphalis margaritacea, Benth. and Hook. E.R.B.G.

Anthemis canescens, Brot.

Anthemis montana, L., v. grandiflora

$x$ Anthemis nobilis, $\mathrm{L}$.

$x$ Anthemis tinctoria, $\mathrm{L}$.

Arnica alpina, Olin and Ladau.

Aster acris, L.

Aster Candollei, Harv.

Aster Lipskyi (Hort.)

Aster longifolius, Lam.

$\times$ Aster paniculatus, Lam.

Aster stellaris, (Hort.)

Balduinia multiflora, Nutt.

$\times$ Bellis perennis, $L$.

Buphthalmum salicifolium, L.

Buphthalmum speciosum, Schreb.

$\times$ Calendula officinalis, $\mathrm{L}$.

$\times$ Carduus crispus, $\mathrm{L}$.

$\times$ Carduus nutans, $L$.

$\times$ Carduus tenuiflorus, Curt.

Cassinia Vauvilliersii, Hook. f.

Catananche caerulea, $\mathrm{L}$.

Catananche caerulea, L., v. alba.

Celmisia coriacea, Raoul.

$\times$ Centaurea aspera, $\mathrm{L}$.

Centaurea atropurpurea, Waldst. and Kit.

Centaurea axillaris, Willd.

$\times$ Centaurea Cyanus, $L$.

Centaurea dealbata, Willd.

Centaurea montana, L.

Centaurea montana, L., v. alba.

Centaurea montana, L., v. lugdunensis, Jord.

$\times$ Centaurea nigra, $L$.

Centaurea praealta, Boiss. and Bal.

$\times$ Centaurea Scabiosa, L.

Centaurea sordida, Willd.

Centaurea variegata, Lam.

Charieis heterophylla, Cass.
Place of Type of Observation. Irritability.

K.R.B.G.

A slight (r)

K.R.B.G.

E.R.B.G.

K.R.B.G.

F.

F.

E.R.B.G.

E.R.B.G.

K.R.B.G.

K.R.B.G.

E.R.B.G.

E.R.B.G.

K.R.B.G.

E.R.B.G.

F.

K.R.B.G.

E.R.B.G.

K.R.B.G.

K.R.B.G.

K.R.B.G.

F.

E.R.B.G.

K.R.B.G.

K.R.B.G.

E.R.B.G.

Rouen B.G. B

E.R.B.G.

K.R.B.G.

F.

K.R.B.G.

C.U.B.G.

C.U.B.G.

K.R.B.G.

F.

E.R.B.G.

E.R.B.G.

E.R.B.G.

E.R.B.G.

K.R.B.G.
C distinct

C. distinct

A distinct

C distinct

C slight

C distinct

B distinct

C distinct

A slight

$\mathrm{C}^{\mathbf{1}}$ marked

C variable

A slight

C variable

C slight but distinct

C distinct (2)

B distinct

C slow

A slight (I)

C distinct ( $\mathrm{I} 6$ )

$\mathrm{C}$ distinct

B distinct

A distinct

C marked (3), Juel records as 'irritable'

C very marked (3)

C distinct

distinct

C slight

$\mathrm{C}^{1}$ distinct

$\mathrm{C}^{1} \quad$ previously recorded as 'irritable'

C distinct (I2)

C distinct (I 2)

C distinct

C distinct

C distinct but variable

C distinct

C distinct (I 6)

C marked

C distinct

C marked 


\section{Genus and Species.}

Chrysanthemum carinatum, Schousb.

$\times$ Chrysanthemum coccineum, Willd. C.P.G. (= Pyrethrum roseum, Bieb.)

Chrysanthemum coronarium, I..

Chrysanthemum corymbosum, $\mathrm{L}$.

$\times$ Chrysanthemum Leucanthemum, L. F.

Chrysanthemum macrophyllum, Waldst. K.R.B.G. and Kit.

Chrysanthemum maximum, Raymond

Chrysanthemum praealtum, Vent.

Chrysocoma Coma-aurea, L.

Chrysopsis villosa, DC.

$x$ Cichorium Intybus, $\mathrm{L}$.

$\times$ Cineraria stellata, (Hort.)

$x$ Cirsium acaule, Weber.

Cirsium eriophorum, Roth.

Cirsium Kerneri, X. (Hort.)

$\times$ Cirsium lanceolatum, Scop.

$x$ Cirsium palustre, Scop.

Coreopsis grandifora, Nutt.

Coreopsis Grantii, Oliv.

Coreopsis tinctoria, Nutt.

Crepis blattarioides, Vil.

$\times$ Crepis virens, $L$.

Dimorphotheca aurantiaca, DC.

Dimorphotheca Ecklonis, DC.

$\times$ Dimorphotheca pluvialis, Moench. K.R.B.G. (= Calendula pluvialis of gardens)

$\times$ Doronicum Pardalianches, L.

$\times$ Dugaldia Hoopesii, Rydberg ( $=$ Helenium Hoopesii, A. Gr.)

Erigeron aurantiacus, Regel.

Erigeron Coulteri, Porter and Coulter

Erigeron glabellus, Nutt.

Erigeron grandiflorus, Hook.

Erigeron macranthus, Nutt.

Erigeron multiradiatus, Benth. and Hook.

Erigeron Rusbyi, A. Gr.

Erigeron speciosus, DC.

$\times$ Gaillardia aristata, Pursh, v. grandi- K.R.B.G. flora, (Hort.)
A.C.G.

C.P.G.

E.R.B.G.

C.P.G.

K.R.B.G.

K.R.B.G.

K.R.B.G.

K.R.B.G.

K.R.B.G.

K.R.B.G.

Place of Type of
Observation. Irritability. Remarks.

C distinct

C distinct (4)

C distinct

C slight

C slight but variable

C slight

C slow but distinct

C distinct

C distinct ( $\mathrm{I}$ )

C only after presentation has begun

C distinct (I6)

A slight

C distinct

B slight

B distinct (I 2)

C distinct

C marked

A slight

C ' $\mathrm{A}$ ' distinct, ' $\mathrm{C}$ ' slight

A distinct

A distinct (3)

C distinct (3)

C marked

C very marked

C marked

C distinct

C distinct

A distinct

A distinct

A distinct

A distinct

C marked

C marked (6)

B ' $A$ ' distinct, ' $B$ ' slight

A distinct

C distinct 


\section{Genus and Species.}

Gerbera hybrida, (Hort.)

Gerbera Jamesoni, Bolus.

Grindelia squarrosa, Dunal.

Helenium autumnale, Lind., v. pumilum, E.R.B.G. Willd.

Heliopsis gratissimus

Heliopsis padula, Wender.

Heliopsis scabra, Dun.

Heliopsis scabra, Dun., v. pitcheriana

Helipterum Manglesii, Muell.

Helipterum roseum, Benth.

Hieracium grandifolium, Sch. Bip.

Hieracium maculatum, Schrank

$\times$ Hieracium murorum, $\mathbf{L}$.

Hieracium pallidum, Biv.

$\times$ Hypochaeris radicata, $L$.

Inula Conyza, $\mathrm{L}$.

Inula glandulosa, Puschk.

Lactuca bracteata, Hook. f.

Lactuca hastata, DC.

$\times$ Lactuca perennis, $\mathrm{L}$.

Lactuca Plumieri, Gren. and Godr.

$\times$ Lapsana communis, $\mathrm{L}$.

Layia gaillardioides, Hook. and Arn.

$\times$ Leontodon hirtus, L. (=L. nudicaulis, Banks)

Leuzea conifera, DC.

$x$ Matricaria Chamomilla, L.

$x$ Matricaria inodora, $\mathrm{L}$.

Moscharia pinnatifida, Ruiz and Pav.

Odontospermum maritimum, Sch. Bip

$x$ Olearia dentata, Moench.

Othonna carnosa, Less.

Othonnopsis cheirifolia, Benth. and Hook. E.R.B.G.

Perezia multiflora, Less.

Pluchea Bulleyana, Jeffrey

$x$ Pulicaria vulgaris, Gaertn.

Rudbeckia ampla, Nelson

Rudbeckia triloba, $\mathrm{L}$.

$\times$ Santolina Chamaecyparissus, L.

Saussurea Yakla, C. B. Clarke
Place of Type of

Observation. Irritability.

K.R.B.G.

E.R.B.G.

E.R.B.G.

K.R.B.G.

E.R.B.G.

K.R.B.G.

E.R.B.G.

K.R.B.G.

K.R.B.G.

K.R.B.G.

K.R.B.G.

$\mathrm{F}$.

K.R.B.G.

F.

E.R.B.G.

K.R.B.G.

K.R.B.G.

K.R.B.G.

K.R.B.G.

K.R.B.G.

F.

K.R.B.G.

K.R.B.G.

K.R.B.G.

F.

F.

K.R.B.G.

E.R.B.G.

K.R.B.G.

E.R.B.G.

C.U.B.G.

E.R.B.G.

E.R.B.G.

K.R.B.G.

E.R.B.G.

E.R.B.G.

K.R.B.G.

B
$\mathrm{Co}$ distinct (7)

$\mathrm{Ce}$ marked (7)

C. distinct

C slight

C distinct (8)

C slow but distinct

C distinct (6)

C veryslow butdistinct

C very marked (9)

A distinct (I)

C slight (3)

C slight (3)

C slight (3)

C slight (3)

C marked (3)

C slight

C distinct

C slow (3), 'A' very clear

C slow (3)

C slight (3)

C slow (3)

C marked (I3)

C slight

C distinct (3)

C marked

A distinct

C distinct

' $A$ ' distinct, ' $B$ ' slight

C marked

A very slight

C variable

A very slight

Ce marked (7)

C distinct

A distinct

C distinct

C slight

C distinct

C distinct 


\section{Genus and Species.}

$\times$ Scorzonera hispanica, L.

Scorzonera purpurea, L.

Senecio adonidifolius, Loisel.

$\times$ Senecio aquaticus, Hill

Senecio bellidioides, Hook. f.

Senecio (hortensis)

$\times$ Senecio Jacobaea, L.

Senecio Ledebouri, Sch. Bip.

Senecio Ligularia, Hook. f.

Senecio Ligularia, Hook. f., v. speciosa

$\times$ Senecio palustris, Hook.

Senecio populifolius, DC.

$\times$ Senecio squalidus, $L$.

Senecio tropaeolifolius, $\mathrm{MacO}$ wan

$\times$ Silybum Marianum, Gaertn。

$\times$ Solidago serotina, Ait.

$x$ Solidago Virgaurea, L。

$\times$ Sonchus asper, L.

$\times$ Sonchus oleraceus, $\mathrm{L}$.

$\times$ Tanacetum vulgare, $\mathrm{L}$.

$\times$ Taraxacum officinale, Weber

Tragopogon orientalis, L.

Ursinia cakilefolia, DC.

Ursinia pulchra, N. E. Br.

Ursinia speciosa, DC.
Place of Type of
Observation. Irritability. Remarks.

K.R.B.G.

C

slow but very distinct (3)

K.R.B.G. C slow but clear (3)

K.R.B.G.

C distinct

F.

B ' $A$ ' distinct, ' $B$ ' slight

E.R.B.G. C distinct

K.R.B.G. C marked (го)

F.

C ' $A$ ' distinct, ' $\mathrm{C}$ ' slight

K.R.B.G. A slight

K.R.B.G. A slight

K.R.B.G. C slight and slow

E.R.B.G. C distinct

E.R.B.G. C marked (II)

K.R.B.G. C distinct

E.R.B.G. $\mathrm{C}$ distinct

C.U.B.G. C distinct (I 2)

F. $\quad$ C distinct

F. $\quad$ C slight

F. $\quad$ C $\quad \operatorname{distinct}(3)$

F. $\quad$ C slight but distinct(3)

E.R.B.G. A distinct (I6)

F. $\quad$ C $\quad \operatorname{distinct}(3)(\mathrm{I} 7)$

K.R.B.G. C slow (3)

K.R.B.G. A distinct

A.C.G. $\quad$ C distinct but variable

A.C.G. B ' $A$ ' distinct, ' $B$ ' slight

\section{Notes.}

(I) Helipterum roseum and Calendula officinalis are recorded by Juel (4) as not irritable, but it must be borne in mind that these show the 'A' type only, and that species which are irritable in these latitudes may not show that character farther north. Chrysocoma Coma-aurea and Ammobium alatum are recorded as irritable by Juel but with a ?.

(2) In Bellis perennis the movement is sometimes slight, and at other times it has been observed to split the anther tube against the comparatively thick and rigid style. The anther tube is frequently quite loose around the style, and the movement can be seen clearly to be due to the stamens and not to any movement of the style.

(3) The lateral movement in the Cichorieae is slow, and the presenta- 
tion of the pollen requires careful observation, as it frequently continues after the style branches have diverged.

(4) Movement is sometimes shown in cut flowers of this species.

(5) This species has orange pollen and dark purple anthers, and the presentation is therefore very easily seen.

(6) In Evigeron multiradiatus and Heliopsis scabra the movement is greatest when the posterior side of the anther tube is touched, giving a movement towards the centre of the capitulum.

(7) In Gerbera Famesoni and Perezia multiflora ${ }^{1}$ the outer florets are much more active than the inner, and the greatest lateral movement is towards the centre of the capitulum. In the former half the pollen is expelled at the first touch, and the rest at the second. In the latter all the pollen is expelled at the first touch. In Gerbera hybrida the pollen is extruded in small quantity, but more rapidly than in the ' $\mathrm{C}$ ' type, and the movement is towards the touch.

(8) In Heliopsis gratissimus the anthers are forced apart on being touched, and the pollen is presented along the slit, which does not at first extend to the base of the anther tube. In the evening, however, the stamens are more or less free from each other in this species. This breaking of the anther tube has been observed in several other genera, e.g. Senecio grandifolius, Celmisia verbascifolia, \&c., and has been recorded by Moore (10) in Cratistylis conocephala.

(9) In Helipterum Manglesii the movement towards the touch through an angle of about twenty degrees is immediately followed by a movement in the reverse direction of about half that magnitude.

(10) This seems to be a garden variety of Senecio populifolius.

(II) In Senecio populifolius the presentation is very distinct, and if the staminal tube is touched at the proper stage the style branches may be seen to protrude and diverge immediately the anthers are retracted.

(I2) Centaurea montana, C. dealbata, Cirsium Kerneri, and Silybum Marianum were recorded in I9I 5 (12).

(13) The mechanism of the lateral movement is very clear in Lapsana communis; the five filaments can be seen quite well. They are slightly bent, and if one of them be touched with the needle-point it is seen to straighten by contraction while the other filaments become more bent, thus tilting the anther tube in the direction of the stimulated filament.

(I4) Irritability of the style has been recorded in the Compositae only in the genus Arctotis (4, 9, and 12).

(I5) An irritable pollen-presentation mechanism similar to that of Compositae was observed in Lobelia thapsoides, Cham., in the Temperate House of the Royal Botanic Gardens, Kew.

(I6) Among the British species recorded as 'iraitable' by Juel (4) are

1 First recorded in I915 (12) under the synonym Gerbera multiflora. 
Inula Helenium, Antennaria dioica, Tanacetum vulgare, Achillea.Ptarmica, A. millefolium, Senecio sarracenicus, Centaurea Cyanus, C. Facea, C. Scabiosa, Cirsium arvense, Carduus crispus, Lapsana communis, and Cichorium Intybus.

(I7) First recorded in August, I9 16, v. literature cited (13).

Acknowledgements are due to the Director of the Royal Botanic Gardens, Kew ; the Regius Keeper of the Royal Botanic Garden, Edinburgh ; the Curator of the Cambridge University Botanic Garden; and to the Curator of the Chelsea Physic Garden, for the facilities which they very kindly granted for the examination of living material.

SUMMARY.

I. Various types of sensitive movements in the Compositae are distinguished.

2. A list of I 49 species and varieties showing irritability is given in which the type and degree of irritability observed are recorded.

3. Irritability was found in 64 per cent. of the species and varieties examined, and in all the tribes of the family except the Eupatorieae and the Vernonieae.

4. Notes on special, interesting cases, such as the explosive irritability in the Mutisieae, and the peculiar, slow movement in the Cichorieae, are appended.

\section{LITERATURE CITED.}

1. Brown, R. : Some Observations on the Natural Family called the Compositae. Trans Linn. Soc., vol. xii, I8I 8.

2. Gray, A.: Notes on the Movement of the Androecium in Sunflowers. Proc. Acad. Nat. Sci., Philadelphia, 1884, p. 287.

3. Hildebrand, F.: Über die Geschlechtsverteilung bei den Compositen. Nov. Act. Leop., Halle, I 869 .

4. Juel, O.: Om pollinationsapparaten hos familjen Compositen. Svensk. Bot. Tidsk., I908, Bd. ii, p. $35^{\circ}$.

5. Knuth, H.: Handbook of Flower Pollination. Eng. Trans, vol. ii, pp. 568 sqq.

6. Kolreuter, J. B. : Vorläufige Nachricht von einigen das Geschlecht der Pflanzen betreff. Versuchen. Dritte Fortsetzung, p. 245. Leipzig, I 766.

7. Linsbauer, L., and Linsbauer, K.: Zur Kenntniss der Reizbarkeit der Centaurea-Filamente nebst Bemerkungen über Stossreizbarkeit. Sitz.-Ber. Akad. Wiss. Wien, Bd. cxvi, Abt. I, I907, p. I 74I.

8. Meenan, T.: On Elasticity in the Filaments of Helianthus. Proc. Acad.Nat. Sci. Philadelphia, I 884 , p. 200.

9. Minden, M. von : Reizbare Griffel von zwei Arctotis-Arten. Flora, Bd. lxxxviii, 190I, p. 238.

10. Moore, Spencer le M. : Alabastra diversa. Part XII. Journal of Botany, vol, xliii, I9oI.

11. Pfeffer, W.: Physiologische Untersuchungen. Leipzig, I873.

12. Small, J.: Preliminary Observations on the Pollen-presentation Mechanism of Arctotis aspera, L. New Phytologist, vol. xiv, I9I 5, p. 2 I6.

13. - Facts and Fancies about Dandelions. Pharm. Journ., vol, xcvii, 1916, p. 157. 
Annats of Botany,

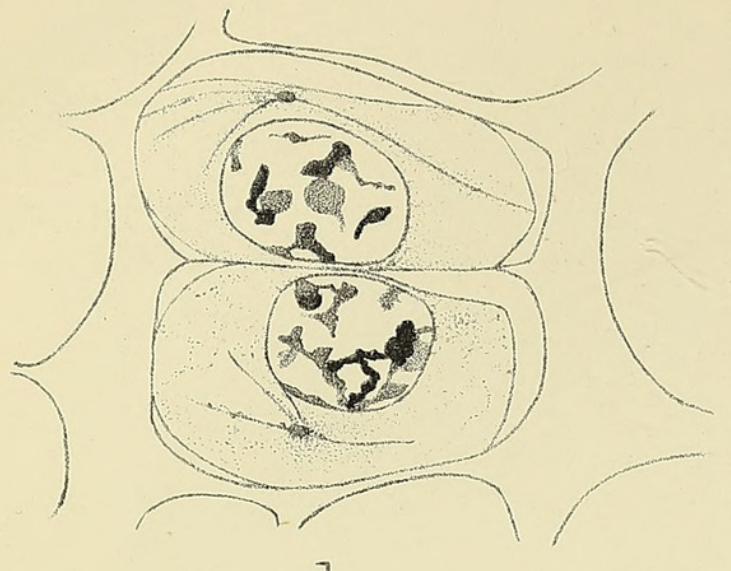

1.
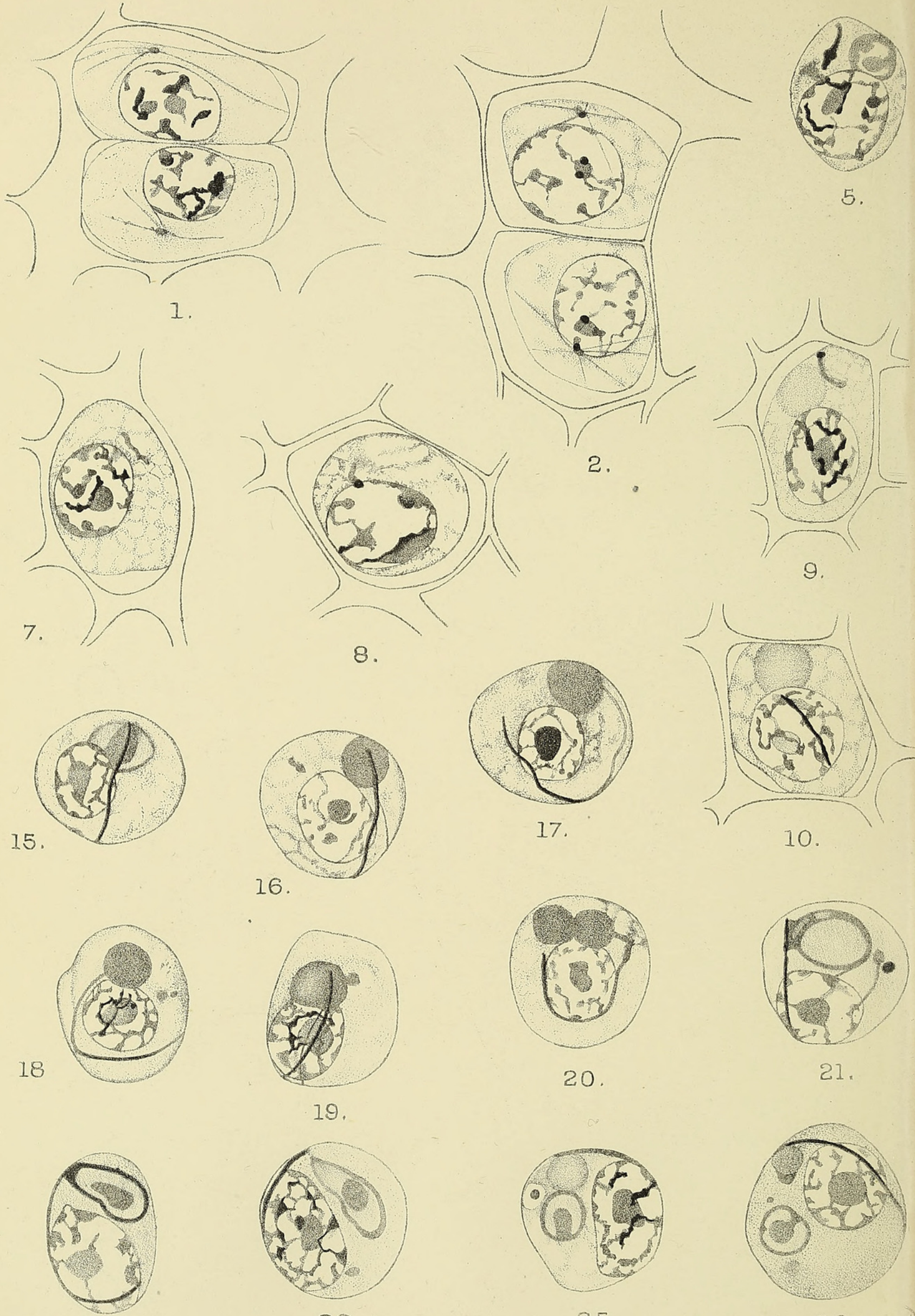

22.
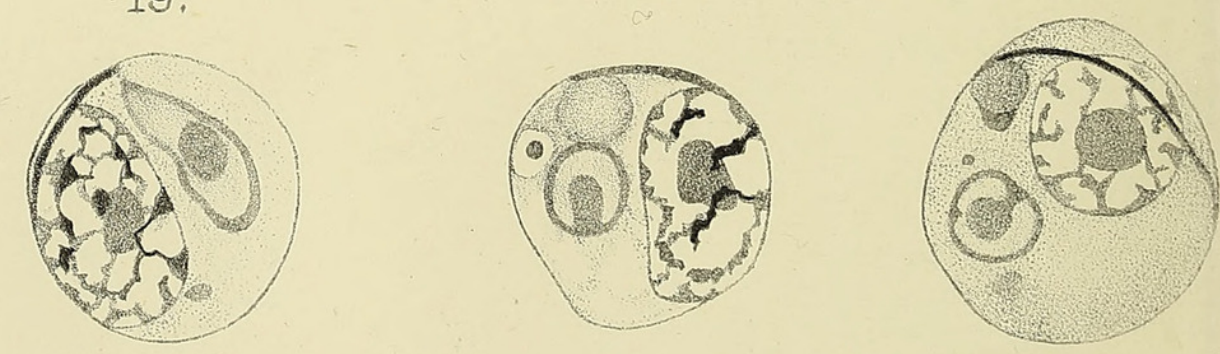

2.3

25.

26. 
Vol, XXXI,PU, XV.

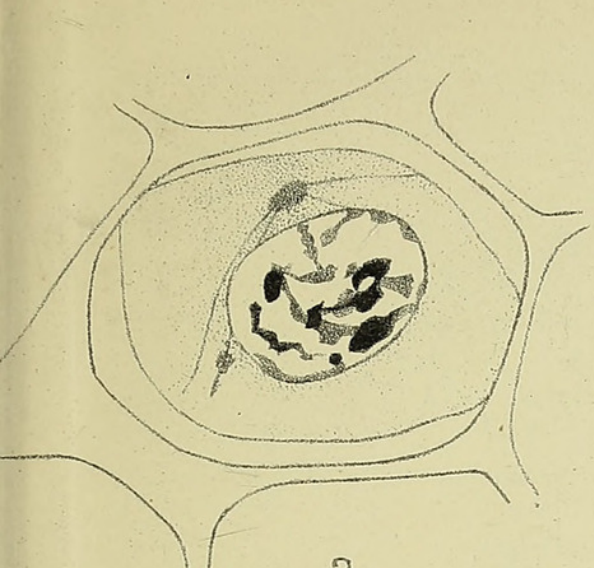

3.

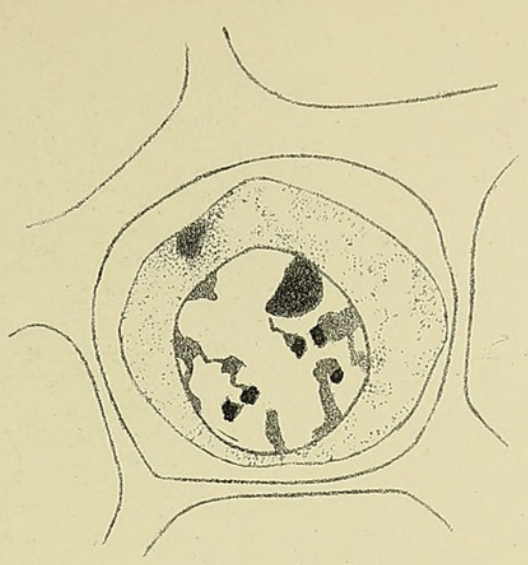

4.

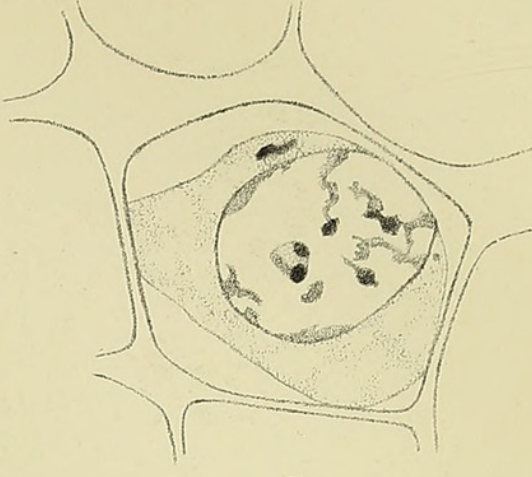

6.

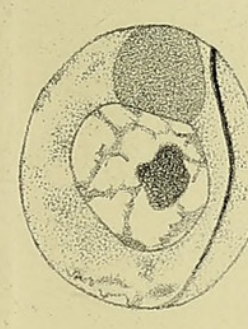

14.

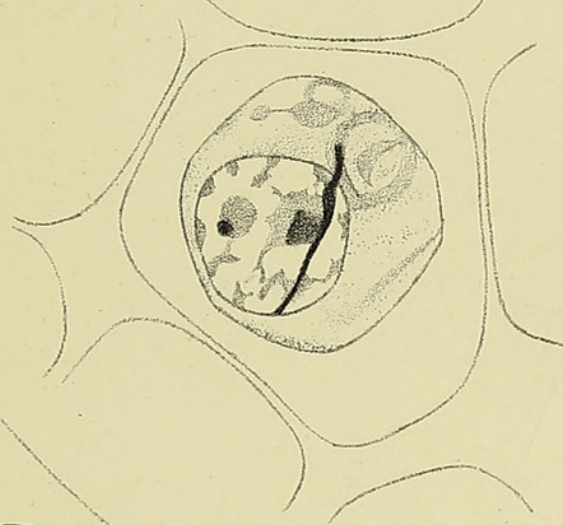

12

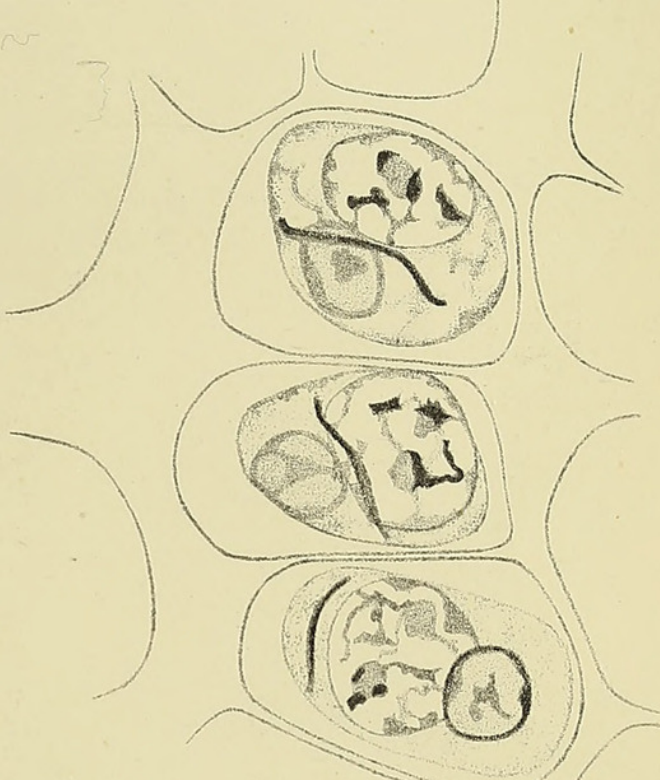

11.

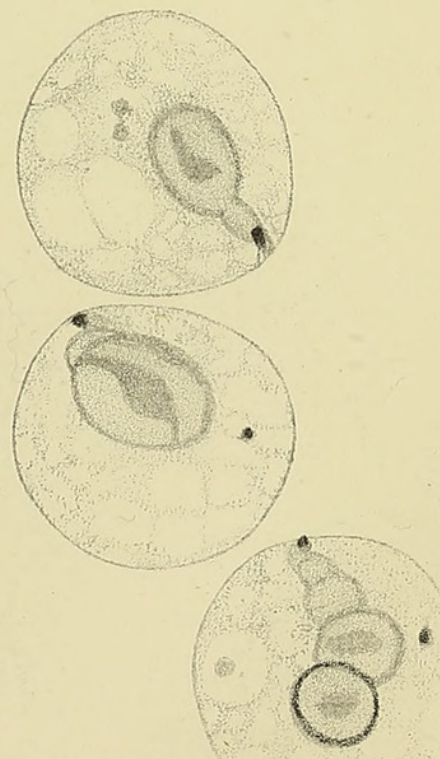

24

13. 
Annals of Botany,

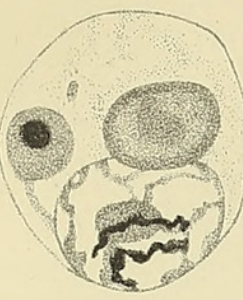

27.
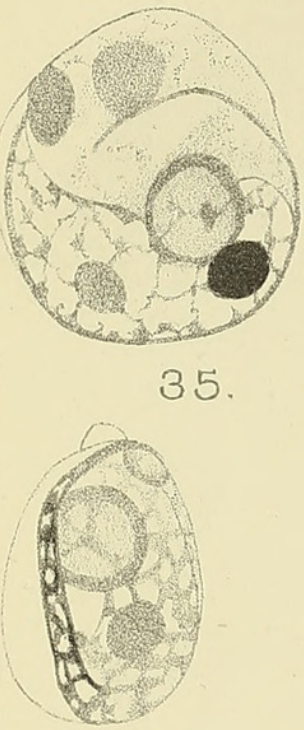

43.

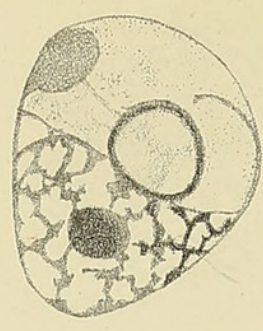

28.
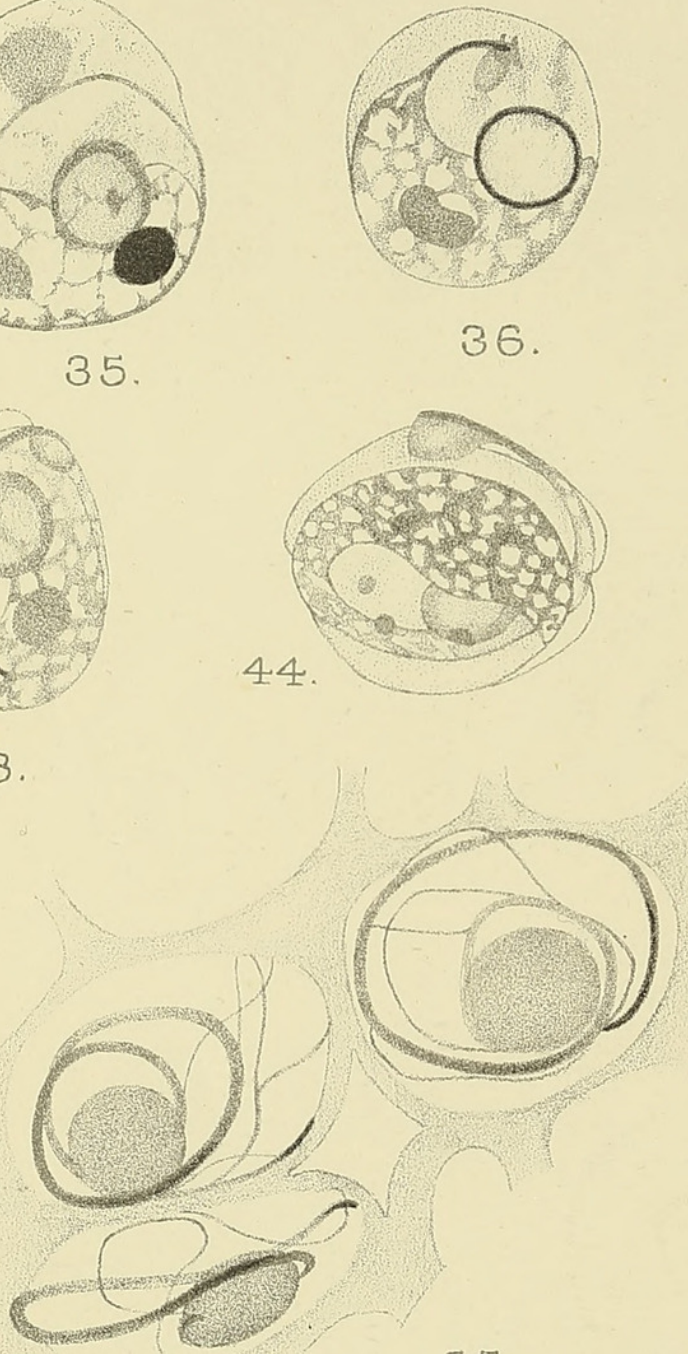

55

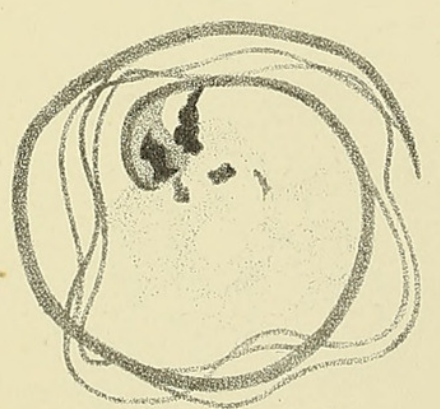

56.

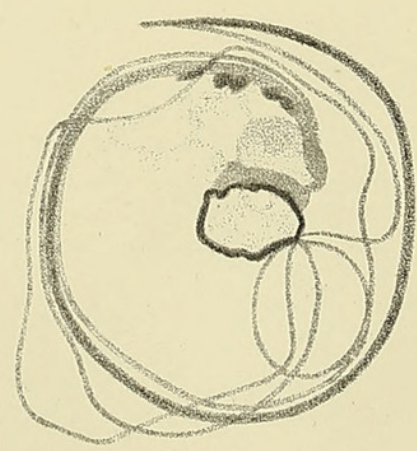

57.

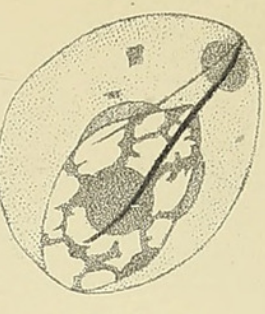

29.
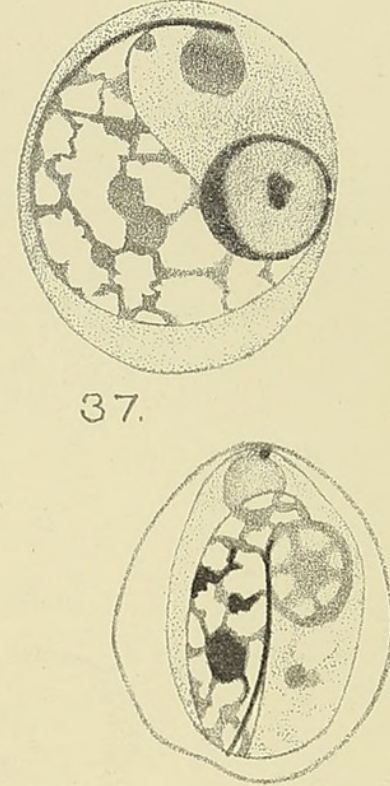

45.

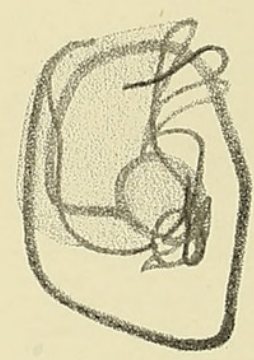

51.

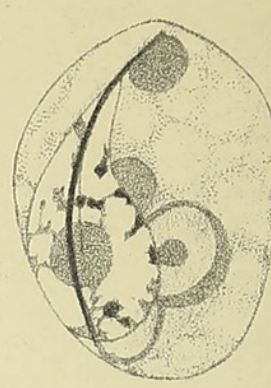

30 .

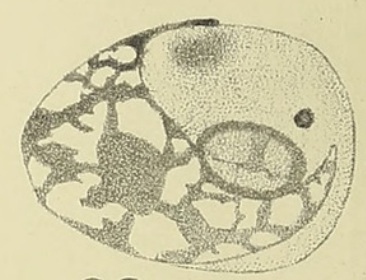

38.

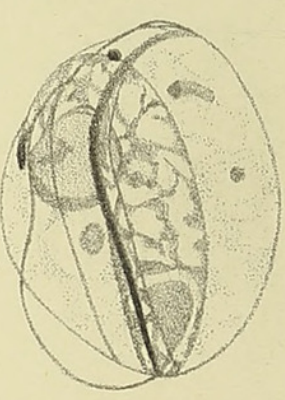

46.

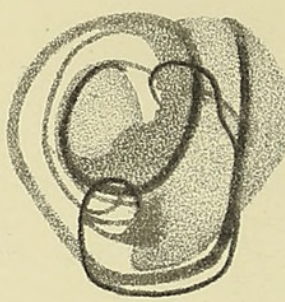

52.

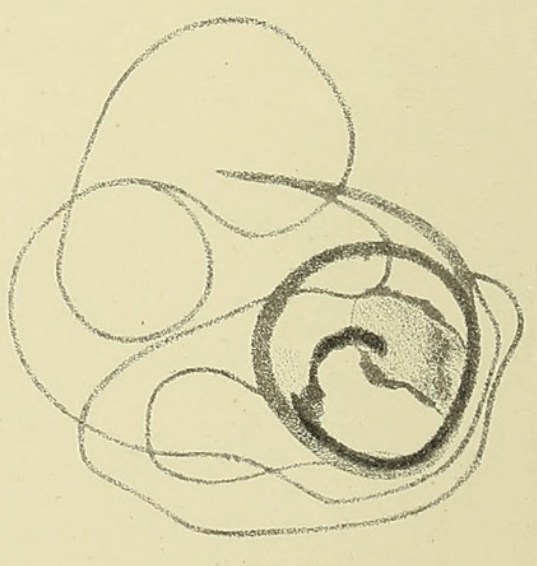

58.

C.E.A. del.

ALLEN - POLYTRICHUM. 
Vol. XXXI,Pl. XVI.

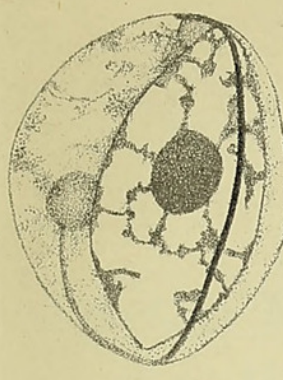

31.

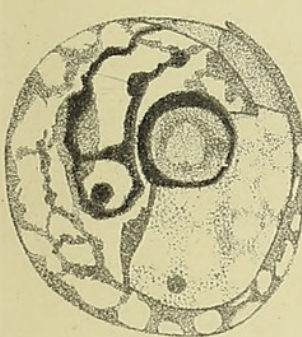

39.

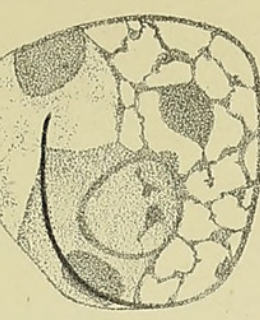

32

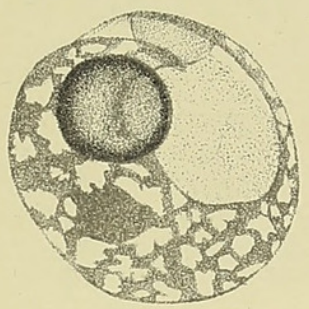

40.

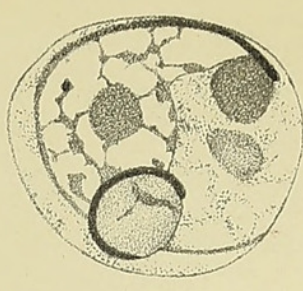

33.

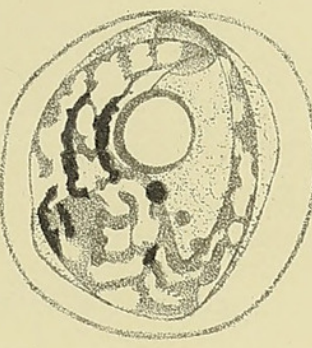

41.

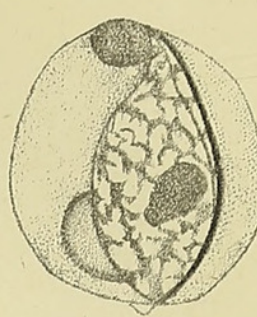

34.

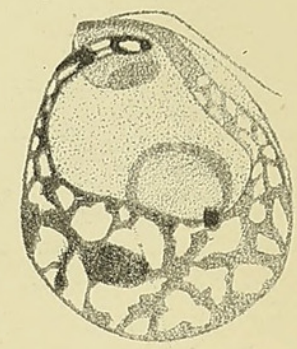

42

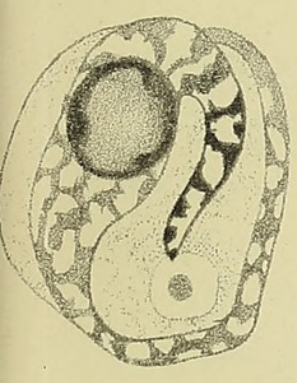

47.

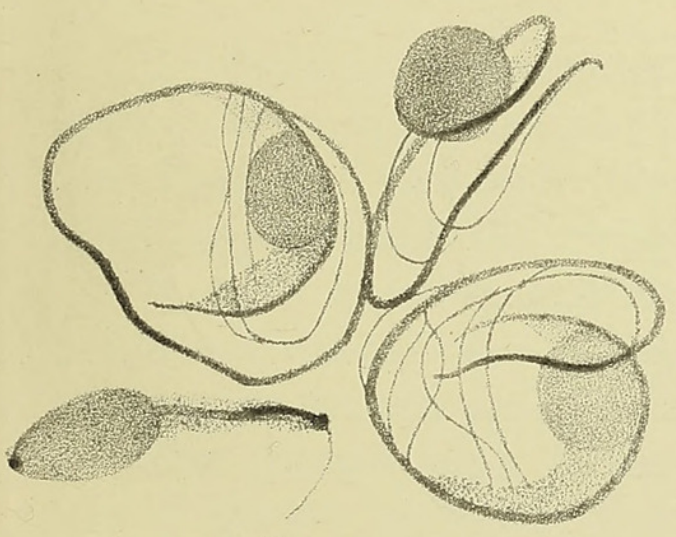

54.

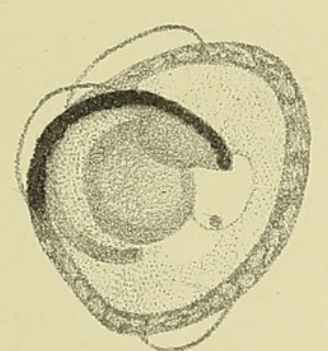

48.

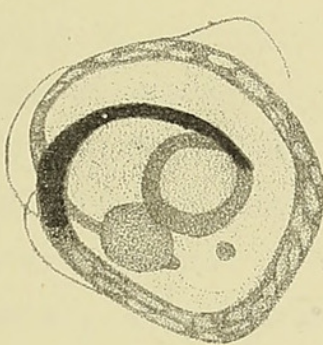

49.
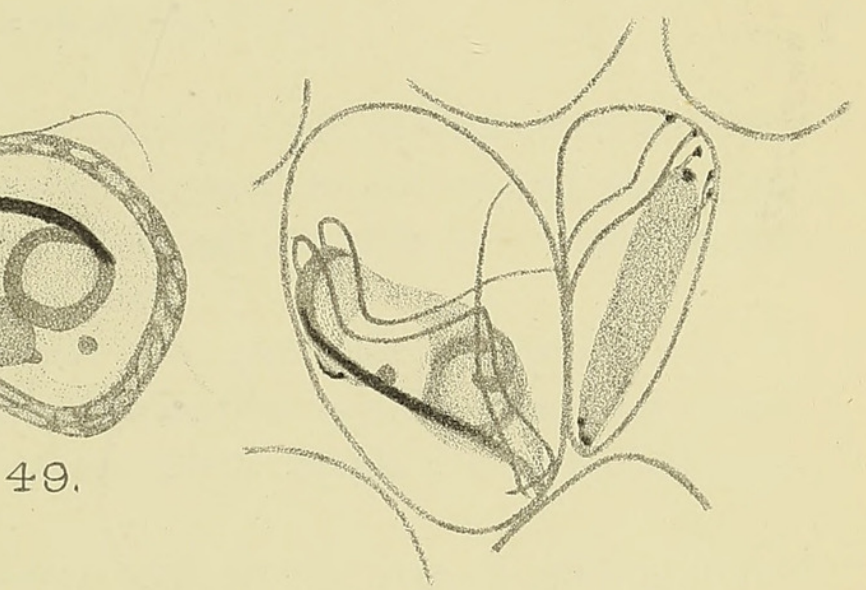

50.
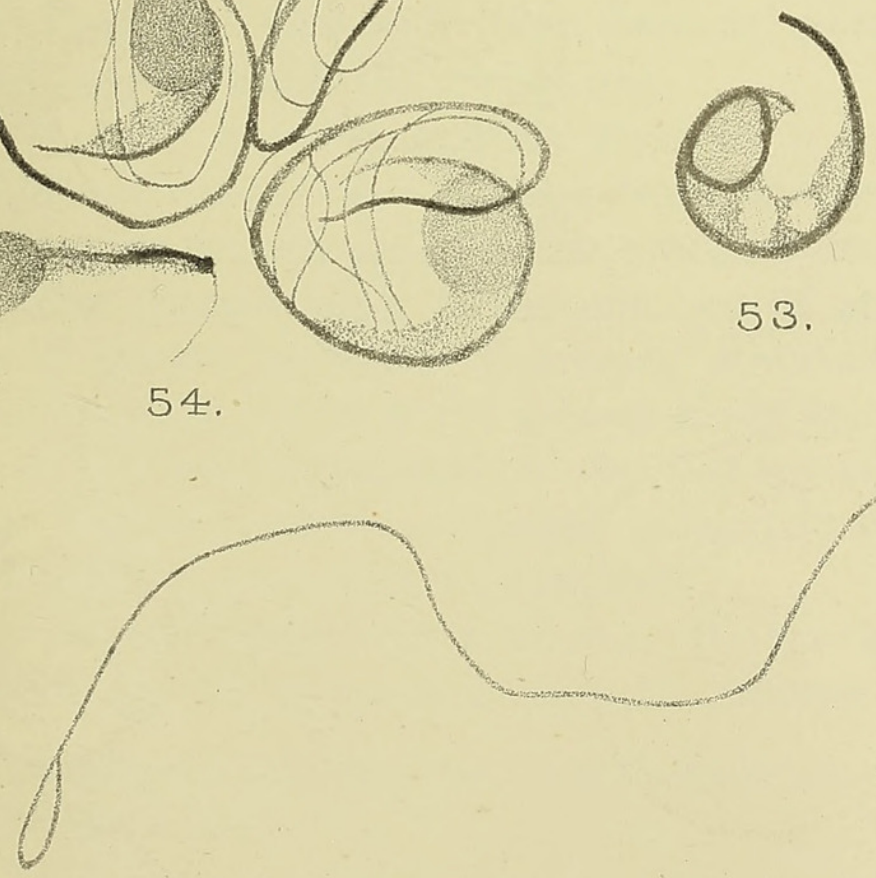

59. 


\section{$2 \mathrm{BHL}$ Biodiversity Heritage Library}

Small, James. 1917. "Irritability of the pollen-presentation mechanism in the Compositae." Annals of botany 31, 261-268.

https://doi.org/10.1093/oxfordjournals.aob.a089645.

View This Item Online: https://www.biodiversitylibrary.org/item/232813

DOI: https://doi.org/10.1093/oxfordjournals.aob.a089645

Permalink: https://www.biodiversitylibrary.org/partpdf/320188

\section{Holding Institution}

Smithsonian Libraries

\section{Sponsored by}

Biodiversity Heritage Library

\section{Copyright \& Reuse}

Copyright Status: Not in copyright. The BHL knows of no copyright restrictions on this item.

This document was created from content at the Biodiversity Heritage Library, the world's largest open access digital library for biodiversity literature and archives. Visit BHL at https://www.biodiversitylibrary.org. 